\title{
BUSINESS CLUSTERS FORMATION FOR REGION DEVELOPMENT IN LITHUANIA
}

\author{
Sonata Staniuliene, Vaida Dickute \\ Vytautas Magnus University, Lithuania \\ sonata.staniuliene@vdu.lt
}

\begin{abstract}
The aim of the research is to prepare proposals for assurance of the business clusters formation regarding the regional development potential upon study of the clusterization of Lithuanian regional companies. After extensive analysis of scientific literature, the qualification of the cluster, their structure, main features, goals and benefits to its members, region, and sector where cluster is based, are observed. From analysis of relevant secondary data the main problems that hinder the development of clusters in distinct regions of Lithuania are distinguished. It is revealed that clusterization in Lithuanian regions lags far behind big cities, it is much more passive and clusters there often reach only the level of a micro-cluster. Clusters are most developed in the tourism and food industries, using traditional means instead of high-techs, failing to benefit from EU support for clustering development. In order to improve the clusterization situation in Lithuania and its development in the regions, more attention and investment are to be allocated for promoting cooperation between the companies and the business and science, research sectors, and joining the international cluster. The state support should be prioritized in the rural regions locating less clusters, forming a reliable means and communication network for these clusters' development.
\end{abstract}

Key words: cluster, clustering, region development.

\section{Introduction}

Due to ever-expanding modern business market and establishing of new enterprises, the productivity and competitiveness are becoming increasingly important for companies' longer existence and strengthening of their development in the local and international markets. This is difficult to assure for small businesses regardless of their activity, because consistent corporate governance requires specialists representing each value chain, the availability of which require additional costs. In this case, they can be supported not by an attempt to compete, but by pursue to cooperate, which can be ensured by the clusters formation, where they are provided with broader opportunities based on collaboration. It can be noted that the cooperation in clusters promotes inter-organizational relations, cooperation between business, education, and government institutions. Representatives of different sectors work together within clusters united by a common goal, without consideration of existing differences in terms of size or expertise.

Due to a growing popularity of modern networked organizations it can be observed that clusters combining these two aspects should become a priority and focus area for each company's successful survival. In addition, the innovation and the knowledge economy contribution, which enable ensuring the competitiveness of the company's activities in the region and innovation for other businesses in the region as well, are positively assessed and widespread. Despite the observed significant benefits of clustering, companies hardly tend to cooperate and are more in favour of their independence, a mistrust of other companies in the region is demonstrated. It can be argued that the clustering process analysis has recently earned a lot of attention in the scientific literature and studies, but there is a lack of approach on ensuring the regional development coherence. In this context, it is possible to formulate the research problem whether enterprise clustering processes are sufficient for their development in different regions of Lithuania.

Consequently, the research object is business clusters formation in Lithuania in the context of regional development, and the aim of the research is to prepare proposals for assurance of the business clusters formation regarding the regional development potential upon study of the clusterization of Lithuanian regional companies. To achieve this aim, the following research objectives are raised: (1) to analyse the concept, structure of cluster and to identify their main features and benefits for companies and the region, (2) to analyse the business clusters formation in Lithuania, (3) to provide proposals for clustering and regional development synergies.

Research methods are analysis of scientific literature on business clusterization for region development and secondary data on clustering in Lithuania analysis.

\section{Materials and Methods}

One of the forms of cooperation is the cluster. Unlike the consortium, which is a temporary partnership, whereas the cartel has an illegal nature, the cluster mostly is defined in the scientific literature according to M. Porter (2000) as a geographical concentration of interconnected companies, specialized suppliers, service providers, companies in associated industries and associated institutions of a certain direction (universities, trade and standards associations), which compete but also cooperate with each other. In fact, Boja (2011) defines the cluster not as a group 
of merely economical, but also as social entities. A Kuah (2002) points out that the cluster is composed of competing but at the same time combining for the improvement of results in the regional profit and growth rate. Following A. Kamarulzaman and N. Mariati (2008), it can be noted that clusters are formed by enterprises similar in their activities, and not merely the ones active in the established geographic area, thus ensuring immediacy between the cluster actors and their formal and informal interaction, agglomeration economy, and high social capital (Stalgiene, 2010). According to R. Jucevicius (2008), the cluster in its narrow meaning is an economic agglomeration that consists of companies operating in the related and supportive activity areas; while the cluster in its broad sense is the regional system of social production and innovation, with a large concentration of actors with different competences, whose close interrelation not only guarantees the economic performance, but also promotes the sharing of knowledge, technology transfer and development of new products. The dynamism of clusters is emphasized, based on knowledge creation, profit enhancement and promotion of innovation. Cluster companies operate in the same market and regional resources, and ensure the competitive advantage compared to other companies in the region (Kind \& Meier zu Kocker, 2013).

Based on R. Jucevicius (2009), the cluster is composed of: (1) kernel - it is usually drawn from major cluster companies that sell their products or services to customers outside the cluster, (2) ancillary activities that require specialized equipment or raw materials, finance and specialized services for the core activities of the cluster, (3) and infrastructure: the 'soft' social infrastructure, composed of educational institutions, training organizations, professional associations, and the 'hard' physical infrastructure of municipal structures.

S. Kind and G. Meier zu Kocker (2012) mention other cluster entities such as financial institutions, businesses, educational and government institutions, media and non-governmental organizations (NGOs). Business enterprise is represented by small and medium-sized enterprises (SMEs), which are defined as the main cluster centre, the kernel. Meanwhile, non-governmental organizations represent the organizations promotion and cooperation, various associations, chambers of commerce that are aiming to support and encourage clustering.

A. Oyarce-Gatica and M. Mardones (2012) provide triple helix model, showing the exchanges and relations between businesses, universities and public institutions in order to increase the region's economic growth. According to the authors, universities provide funding for research and development (R \& D), into which the state invests to achieve business sector growth. Thus, these elements ensure overall economic growth of the region and the state. According to them, all three elements interact with each other, including the fields of production, distribution, new and useful knowledge, information and innovation by their activities. Moreover, the relations of the cluster elements create a social network, through which companies receive a greater benefit for a better dissemination of information and knowledge between the cluster actors.

R. Jucevicius (2008) suggests the following cluster classification: (1) micro clusters - a group of 5-15 small enterprises, cooperating in various activities such as co-organized learning, marketing, jointly designed and developed product; (2) value chains, consisting of companies engaged in various sectors, creating specific value chains in order to ensure a productive cluster activity; (3) supply chains, consisting of companies that ensure supply of materials and other components necessary for production performed by larger companies; (4) sectoral clusters, made up of a group of companies engaged in similar activities, which develops a network of excellence; (5) geographic clusters that are divided into local, regional, national and international according to their geographical area.

Summarizing Kuah A. (2002), R. Jucevicius (2008) and Cluster Network of Excellence (2016), the following key clusters benefits for businesses are highlighted: cluster-owned companies are more productive and profitable; faster growth companies; the opportunity is provided to compete not only in domestic but also in international markets; it is easier to go beyond the limits of other markets for co-organized marketing and sales; companies attract new investors; the opportunity is provided to obtain cheaper, faster and easier access to specialized information and knowledge; creation of activity synergies; the opportunity is provided to implement large orders and to participate in public procurement; easier implementation of value chain activities by allocating them among different entities; skilled labour force; increased competitiveness of all cluster system; creating more favourable conditions for innovation; socialization and community culture.

Establishment of clusters promotes business development in the area where they are located, and combining into the clusters is useful not only for businesses but also for the whole region. The formation of such clusters has been recently observed throughout the world, and the regions where the clusters concentration is large become the economic engine of all the surrounding regions.

R. Zadeh (2007) states that the benefits of clusters can be grouped into the company, regional and national levels. In case of the regional level, the benefit 


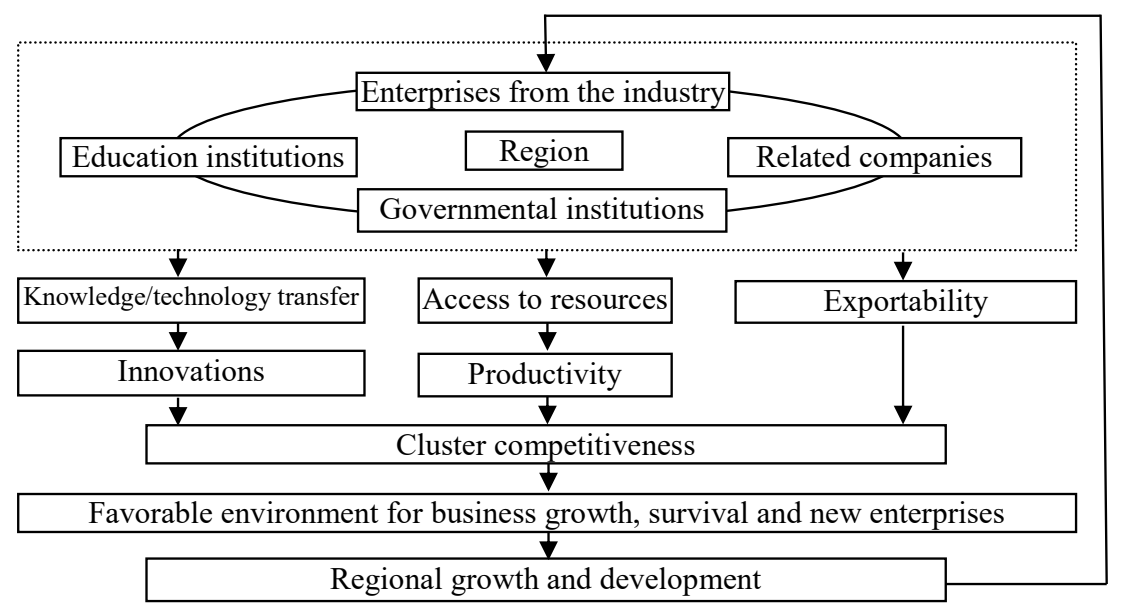

Source: According Z. Garanti ir A. Zvirbule - Berzina (2013).

Figure 1. Region Cluster Effect on Regional Growth and Development.

is linked to specific local companies and it includes facilitating access to the relevant labour, research, knowledge, specific professional services, suppliers and customers and innovative products in the region. Therefore, the emergence of clusters can often be based on the promotion and support of the regional authorities. Clusters are formed in regions regardless of the quality of the business environment, but a better business environment provides better conditions for successful operations and development of clusters. According to K. Mills, E. Reynolds and A. Reamer (2008), and R. Jucevicius (2003), clusters are the main mechanism for increasing of regional competitiveness. J. Cincikaite and G. Belazariene (2001) state that clusters increase the regional competitiveness by improving productivity of industries and adaptation to a changing environment, innovation, and continuously expand cluster boundaries by attracting new members to the cluster from other regions. Meanwhile, $\mathrm{Z}$. Garanti and A. Zvirbule-Berzina (2013) provide a broader scheme depicting the influence of a cluster to the region (see Fig. 1):

They argue that combining into clusters allows companies to secure economic growth and development, and this influences the whole region's economic growth and development. The resulting cluster, particularly in influencing corporate activities and educational and public institutions, provides benefits for the entire region, and according to $\mathrm{K}$. Mills, E. Reynolds and A. Reamer (2008), cluster competitiveness is conducive to the whole region in business growth and development, and to the creation of competitive advantages. Then non-cluster companies try to keep up with the cluster companies and be competitive with them, and this allows for expansion of the regional business market. The correlation of the clusters formation with economic indicators has been analysed (Ketels, 2003): the stronger the clusters in the region, the higher are wages there, the cluster is associated with a higher GDP, and the improved corporate performance is evidenced as well. Cluster activities may not only bring tangible economic benefits to individual regions, rural areas, but at the same time can improve the prevailing social situation: reduce the number of harmful addictions, conflict situations, thus allowing the state to reduce the funds allocated for social benefits. There is an opportunity to improve living conditions in the regions, to raise the level of infrastructure, to invest in social care, culture, etc. Over time, this should result in the reduction of regional and territorial exclusion.

On the other hand, according to R. Jucevicius (2009), S. Kind, G. Meier zu Kocker (2012), Rosenfeld (2002), a success of the cluster activity depends also on regional restrictions and insularity, low supply of industrial real estate, poor infrastructure in the region, the obtained state financial support, utilization of innovation and technical capacity or investment. Ch. Ketels (2003) highlights failures associated with government intervention in the market, misused support to clusterization, conflict of interest, or the support of high-tech clusters even when there are no necessary conditions in the region. Removal of cluster barriers and promotion of cluster processes should be the priority of national and regional policies, as the impact of clusters on economic development and wage growth is proven and significant.

Methods. This study was extensive analysis of scientific literature, as well as analysis of available relevant secondary data, which was collected from government bodies, NGOs, foreign development agencies, relevant local organisations, funded projects reports, previous researches, assessments, and their reports of clusterization, etc. A source of secondary data analysis was both quantitative and qualitative data. The aim of a secondary analysis is usually 
to address new research questions by analysing previously collected data, so here research questions are: (1) the development of clusterization in Lithuania and its regions, as well as the current situation thereof, (2) the cluster distribution in separate Lithuanian regions, (3) clusterization in individual sectors, (4) the benefit of clusterization for the cluster members and the regional development, (5) financial and other support provided to clusters by the state, and (6) issues faced in individual regions by the companies that are determined to form cluster. During the data processing the content analysis method has been used, by which clusterization of Lithuanian regions has been examined.

\section{Results and Discussion}

Accelerated formation of clusters in Lithuania started in the period of 2010 to 2013, when 31 clusters were established. Currently, there are 51 clusters in Lithuania (KlasterLT, 2016). In the Global Competitiveness Report of 2014-2015, Lithuania occupies the 89th place out of 148 countries by the development status of clusters and is ahead of Latvia (the 90th place), but lags behind Estonia (the 76th place). It is positive that Lithuania has achieved the best result in the past five years in this list. However, clusters in Lithuania are relatively new and small the average cluster age being 3.1 years, consisting of approximately 12 companies, academic and research institutions and other entities. It can be argued that clustering processes in Lithuania are still quite new and requiring attention and support of the state and cluster consulting firms.

The study shows that part of the clusters has only started formation, is still in the initial stage or there are merely groups of companies, unified by pursue to take advantage of support of the EU Structural Funds. The clusters are usually formed by smaller enterprises featuring the widest range of activities, in order to obtain specific resources or services that they are lacking, which can be ensured by cooperation of the cluster. To achieve all this, financial support is necessary, which can be allocated by the authorities and the educational and research institutions included into the cluster, where the required specialists will be prepared.

Based on the study of the source clusters in Lithuania, it can be said that although clusterization gains more and more attention, the clusters formation processes are different in each sector. In Lithuania, clusters are basically present in 7 business sectors: chemicals, electronics, food and beverage, wood and furniture industry and services that are changing the client's physical or mental qualities and material good characteristics, and information services sectors.
The companies most actively combine clusters by common purpose in the service sector (Mrazauskaite, 2016) - there are 32 clusters; so, given this fact it can be said that there are more companies in Lithuania engaged in the services sector, and clustering is more developed there due to better conditions. The most developed sectors are medical and tourism sectors, including their clusters that are becoming more in numbers (Navickas \& Malakauskaite, 2009). Meanwhile, in areas such as IT services and the automotive industry, there is a need for new investment and attracting new members in order to facilitate their activities, by combining competent professionals. For example, one such cluster is the cluster of Baltic automotive parts established in 2013, which currently has 14 members and despite of that still relies on intermediaries for production of the required products and seeks for new members (Razmaite, 2013). Currently, the maximum number of clusters is recorded in the information technology (IT), tourism and medical and health sectors. The activity in these sectors is probably determined by their specifics, as the service sector is easier to build, while the business is more mobile. The companies are used to cooperate with each other in the past as well, even without forming a cluster. For example, 'in order to attract an even greater flow of tourists, especially from abroad, and in order to steadily promote and advertise their local country or region's tourism by consistently formulating and implementing strategies, the tourism sector enterprises have naturally become aware of the need to cooperate' (Lasionis, 2016). Meanwhile, the food and beverage and wood industry clusters operate most successfully in the industry area, although not every potential is utilised in these sectors, whereas the electronics and the chemical industry are facing the issues of limited resources and skilled manpower (Svetkauskas, 2003).

Clusters formation in Lithuania requires focus on regions with relatively developed business, industry and technology infrastructure that provides the necessary cluster resources and services. The clusters in Lithuania are mainly established in the economically strongest cities (even 76 percent of them are located in Vilnius, Klaipeda, Kaunas and Alytus), where there is a variety of resource-rich service providers required for clusters. However, in Lithuanian regions certain micro-clusters can also be detected, while some regions have their own clear specifics (Birzai, Druskininkai, Kedainiai, Mazeikiai, Ignalina, etc.) (Cluster map of Lithuania, 2016.). The study counted only 140 (24 percent) regional companies from a total of 580 companies belonging to clusters in Lithuania. Of all the clusters in Lithuania, only 26 of the 51 clusters have at least one member located not in a major city. 
Clear Digital World Cluster, Natural Mineral Water Cluster and Uzupis Creative Cluster go beyond the boundaries of the region, adding members of the neighbouring Latvia, Estonia, Belarus, where the latter cluster even has 2 members from Great Britain. However, they cannot be designated as international level clusters and the role of internationalization in the cluster having a higher level than micro-clusters is clearly insufficient in the regional level as well. In particular, in the fields of IT services and hightech, as well as in medical area, most clusters are exceptionally primarily based in Vilnius, some in Kaunas, Klaipeda and Siauliai, without any members from more distant Lithuanian regions.

In the distant regions, located away from the state capital, and especially in rural areas or small resort towns the most typical representatives are those of the tourism clusters (seeTable 1) - there are 6 of them in total: clusters of Anyksciai, Pamarys, Zemaitija, Ignalina, Birzai and Kedainiai tourism. They all or almost all have members that are not located in big cities but rather based in remote areas, as well as their members - cluster coordinators. Also, about half of the members of the food industry clusters are located in non-metropolitan areas and contribute to sustainable regional development. It should be noted that the regional distribution of clusters can be clearly linked to the nature of activities of cluster members, which requires the rural tourism attraction centres situated in the regions, agricultural resources or cheaper labour available therein. The opposite reasons are inherent in the demand of IT, medical or other high-tech

Data analysis of regional clustering in Lithuania

Table 1

\begin{tabular}{|c|c|c|c|c|}
\hline Cluster name & Regional & Type & Coordinator & $\begin{array}{l}\text { Funding of Inoklaster } \\
\mathrm{LT}(+)\end{array}$ \\
\hline Anyksciai Tourism & $19 / 20$ & Micro cluster & Association, Anykščiai & - \\
\hline Pamarys Tourism & $18 / 20$ & Value chain & Association, Klaipeda dist. & - \\
\hline Zemaitija Tourism & $13 / 14$ & Micro cluster & Association, Plunge & - \\
\hline Ignalina Tourism & $13 / 14$ & Sectoral & Association, Ignalina & - \\
\hline Birzai Tourism & $13 / 13$ & Micro cluster & Association, Birzai district & - \\
\hline Kedainiai Region Tourism & $8 / 9$ & Micro cluster & PI, Kedainiai & - \\
\hline National Food Farm & $6 / 9$ & Micro cluster & Association, Kauno dist. & - \\
\hline Food (Fruits and Vegetables) & $3 / 5$ & Sectoral & JSC, Kaunas & Absence of contract \\
\hline Smart Food & $3 / 8$ & Micro cluster & Association, Vilnius & - \\
\hline $\begin{array}{l}\text { Lithuania Car Parts Producers/ } \\
\text { Exp. }\end{array}$ & $7 / 14$ & Micro cluster & Association, Siauliai & - \\
\hline Baltic Car Parts & $5 / 17$ & Micro cluster & Association, Kaunas & - \\
\hline $\begin{array}{l}\text { Energy-efficient and Passive } \\
\text { Houses }\end{array}$ & $5 / 8$ & Sectoral & Association, Kretinga & - \\
\hline Baltic Furniture & $2 / 8$ & Sectoral & Association, Siauliai & - \\
\hline Bio Power Plant Development & $2 / 4$ & Sectoral & JSC, Kedainiai & $74424 \mathrm{Eu}$, accomplished \\
\hline Clear Digital World & $1 / 13$ & Micro cluster & JSC, Vilnius & $254828 \mathrm{Eu}$, accomplished \\
\hline Fotoelectricity Technologies & $2 / 26$ & Sectoral & PI, Vilnius & $\begin{array}{l}3445722 \mathrm{Eu}, \\
\text { accomplished }\end{array}$ \\
\hline Innovative Energy-Consumption & $2 / 9$ & Sectoral & JSC, Vilnius & Absence of contract \\
\hline Smart IT Cluster & $1 / 12$ & Value chain & PI, Vilnius & Terminated \\
\hline Lithuanian Laser Association & $1 / 17$ & Sectoral & Association, Vilnius & - \\
\hline Lithuania Medical Tourism & $2 / 14$ & Value chain & Association, Vilnius & - \\
\hline Plastics and New Materials & $4 / 15$ & Sectoral & PI, Vilnius & Absence of contract \\
\hline Lithuanian Plastics & $2 / 13$ & Micro cluster & Association, Siauliai & - \\
\hline Natural Mineral Water & $1 / 9$ & Sectoral & JSC, Vilnius & Absence of contract \\
\hline New Generation of Science and B. & $2 / 28$ & Value chain & Association, Klaipėda & - \\
\hline Health Cluster iVita & $2 / 11$ & Micro cluster & JSC, Kaunas & $102508 \mathrm{Eu}$, accomplished \\
\hline International Health & $3 / 12$ & Sectoral & Association, Vilnius & - \\
\hline
\end{tabular}


to provide for both sufficiently competent human resources and technological equipment, so their clustering is absolutely not spread in rural areas. The difference in excellence and at the same time the level of objectives raised is reflected by diverse cluster type chosen, since the micro-cluster type is dominant in rural regions, including the strengthening tasks of organization level functions, whereas the clusters located in major cities often reach the sector level objectives, when they pursue to become specific skills development centres, or the value chain type objectives, when the cluster unites the members that offer different performance to the market in order to complete customer satisfaction by cluster capabilities.

The formation objectives nominated by clusters are mostly corporate development opportunities, innovation and increasing innovative applications, new investment attraction and communications creation and support between different companies, while less common objectives are the analysis of clusters formation experience, public procurement, technical standards and private infrastructure project development.

Among the most favourable and best conditions for promoting cluster development in Lithuania are rather cheap qualified workforce, a convenient location for logistics, well-developed logistics, good infrastructure and technology. An important factor in the development of rural areas is an innovative product design and development. The most common issue discussed in scientific debate and practical analysis is agro-tourism development and the social value created thereby, synergy emerging from a new producer cooperatives, development of clusters and rural innovation incubators (Milone \& Ventura, 2004).

The main identified problems of clusterization development in Lithuania are such as lack in cooperation culture, search for distant partners, while considering the nearby businesses as competitors, lack of responsibility for the quality of operations after the merger, lack of interest in innovation and successful activities of the merging company, which does not encourage improvement, lack of business-to-business confidence, which impedes attraction of new members into clusters, low management level of competence and limited local raw material resources (Pasiliauskas, 2012). The clustering process is also prevented by the emigration of the skilled labour force in the regions, and the resulting shortage of skilled labour force as well as unfavourable assessment of particular specialties by the youth (Žinių ekonomikos formumas, 2012; Jucevicius, 2010).

As for each company, the clusters are facing major challenges in the formation and the market establishment stage, when they are most in need of financial support in order to accelerate and facilitate this stage. Complete cluster formation generally requires about three years and the state involvement and support is needed mostly up to establishment of the cluster. In 2011, when the peak of clusters formation was reached, the companies were mostly encouraged to combine by a greater access to the European Union (EU) funding, while recently clusters are being formed naturally - for the economic benefit. However, some data proves the cluster members' passivity in coordinators' activity, and the interest in coordinators' status shows that the majority of them are structures of association type, while public institutions or limited liability companies that would have more political and economic incentives to develop clusterization in the regions, are significantly less common.

However, only a quarter of all countable clusters can be regarded as naturally formed clusters. Another reason for clusterization - emerge of information technology, tourism clusters are more initiated by the state, local authorities, or certain associations of these sectors, not at the company's initiative.

Emerging clusters initiatives in Lithuania are eligible for the European Union financial support. According to Ziniu ekonomikos forumas (2012) the main EU support measures 'Inoklaster LT' and 'Inoklaster LT +' have been validated and confirmed in 2008, thus approving the Lithuanian Innovation Strategy of 2010-2020, which highlights the companies' involvement in the international promotion of cluster opportunities and provides for the plan of support measures for clusters formation and further operation of clusters competencies network. Under 'Inoklaster LT' measure the support of over 568 thousand EUR by 6 applications was provided alone in 2016 (for more information see http://lvpa.lt/lt/paraiskos/priemonesinoklaster-lt-antras-kvietimas-342). Another planned support measure 'Ingeb E-3' has been approved for strengthening of the innovation system in order to ensure the development of R \& D. As for Lithuania clusters internationalization, it should be noted that there is a notable Lithuanian cluster involvement in various international projects, such as the 'Baltic Sea Region 2007 - 2013' and 'Eureka Eurostars' (Global Cluster Observatory, 2016.).

Nevertheless, only 15 of the 51 clusters were able to take advantage of these support measures, and none of the major tourism and food industry clusters active in Lithuanian remote areas did not utilise the support, which means that the EU support had no impact for clustering development in the regions. There are a number of barriers, which prevent utilisation of support programs for each cluster initiative. Support can be given only to cluster initiatives, which aim to find out the cluster emergence opportunities and its potential participants to develop or strengthen national or regional level cluster, to form or strengthen cross- 
sectoral cluster, to create or strengthen a joint regional business system, to form or improve the competence networks linking different areas of expertise. On this basis, it can be said that only potential clusters or clusters that have already started formation process are able to get the support. Support measures 'Inoklaster LT' and 'Inoklaster LT +' require at least 5 enterprises, while 'Ingeb E-3' - at least 10 enterprises to be involved to receive the support. It can be argued that the required number is not large, and there is a possibility that companies can combine their activities in order to benefit from the support, while the regional micro-clusters fail to do so. According to the data provided by Ziniu ekonomikos forumas (2012), the consultations of innovative service providers provided to businesses on the importance and benefits of clusters can help to reduce this risk. Currently these consulting services are provided by 'Lithuanian Innovation Centre', 'Science, Innovation and Technology Agency' and Public Institution "Enterprise Lithuania", which consult Lithuanian businesses on the clusters creation (Briediene, 2013), formation, growth, development, governance and legal issues, and support in finding the required financing resources and new cluster members not only in Lithuania but also abroad.

\section{Conclusions}

Cluster policy is becoming an attractive alternative to the traditional and unjustified industrial policy, geared to the priority sectors of the economy and corporate sponsorship, because it is based on the assumption that the regional well-being is determined not by the specific individual companies, but rather on the operation of the groups of them linked by productive relationship in the region. Therefore, the main subject of the cluster policy is creation of the entire industrial system of the region, supporting productive relationship among actors.

It has been established that clusterization processes in Lithuania are still relatively new compared with international experience. The more distinct clusterization processes take place in the service sector in Lithuania, as compared to the industry. The main problems that hinder the development of clusters in
Lithuania are passivity of the cluster members on the predominant role of a coordinator, lack in confidence among members, education, and government sectors, which impedes attraction of new members, emerging lack of skilled labour force due to emigration, rising prices of labour resources and limited local resources.

Clusterization in Lithuanian regions lags far behind the big cities, is much more passive, clusters there often reach only the level of a micro-cluster. Clusters are most developed in the tourism and food industries, using traditional means of action, rather than the modern high-techs, employing cheaper labour force in the regions, failing to become a centre of excellence and benefit from the EU support for clustering development.

From the point of view of separate regions, the state support should be prioritized in the rural regions locating less clusters rather than in the regions surrounding major cities. In order to improve the clusterization situation in Lithuania and its development in the regions, more attention and investment are to be allocated for promoting cooperation between the companies, the business and science, research sectors, strengthening their confidence in each other and interrelations, promoting development, growth of existing clusters, their joining the international clusters and formation initiatives of new clusters, creation of support programs for implementation of easy clustering processes. Cluster management after its formation has to focus on each management areas such as training, competence and development, information dissemination and communication, collaboration, marketing and internationalization. Higher education institutions ensure preparation of a skilled workforce for the cluster, legal counselling and the opportunity to benefit from the EU and state support, which enable $\mathrm{R} \& \mathrm{D}$ and training infrastructure. The clusterization processes need to be effectively managed, aligning the bottom-up and top-down processes, and linked to the education, business and technology infrastructures, in order to ensure a longer cluster survival and its increased efficiency for the enterprises and the entire region development.

\section{References}

1. Boja, C. (2011). Clusters Models, Factors and Characteristics. International Journal of Economic Practices and Theories, Vol. 1, No. 1, $34-43$.

2. Briedienè, R. (2013). Klasteris: 'Anykščiai taps kultūrinio turizmo sostine' (Cluster: ,Anyksciai Will Became the Capital of Cultural Tourism ). Retrieved March 1, 2017, from: http://www.temainfo.lt/klasteris-anyksciai-tapskulturinio-turizmo-sostine/. (in Lithuanian).

3. Činčikaitè, J., \& Belazarienè, G. (2001). Klasteriai ir regionų konkurencingumas (Clusters and Regional Competitiveness). Regionu pletra-2001: tarptautine moksliné konferencija, 10 - 14. Kaunas: KTU. (in Lithuanian).

4. Global Cluster Observatory (2017). Retrieved March 1, 2017, from: http://www.clusterobservatory.eu. (in Lithuanian). 
5. Garanti, Z., \& Zvirbule-Berzina, A. (2013). Regional cluster initiatives as a driving force. For regional development European integration studies, No. 7, 91 - 101. DOI: 10.5755/j01.eis.0.7.3677.

6. Jucevičius, R. (2003). Klasteriai - stiprus postūmis šalies konkurencingumui (Clusters - A Strong Impetus to the Country's Competitiveness). Euroverslo naujienos, Nr. 27. Retrieved March 1, 2017, from: http://www.verslobanga. lt/lt/leidinys.full/3eacdcad5f6ae. (in Lithuanian).

7. Jucevičius, R. (2008). Klasteriu ABC (Clusters ' $A B C$ ). Vilnius: Klasterių kompetencijos tinklas (in Lithuanian).

8. Jucevičius, R. (2009). Klasteriu vadovas (Clusters ' Guide). Vilnius:Klasterių kompetencijos tinklas(in Lithuanian).

9. Jucevičius, G. (2010). Klasterizacija Lietuvoje (Clusterization in Lithuania). Retrieved March 2, 2017, from: http:// www.technologijos.1t/n/mtl/straipsnis?name=S-11299. (in Lithuanian).

10. Kamarulzaman, A., \& Mariati, N. (2008). Cluster-Based Policy Making: Assessing Performance and Sustaining Competitiveness. Review of Policy Research, 4(25), 349 - 375. DOI: 10.1111/j.1541-1338.2008.00336.x.

11. Ketels, Ch. (2003). The Development of the cluster concept - present experiences and further developments. $N R W$ conference on clusters. Duisburg.

12. Kind, S., \& Meier zu Köcker, G. (2012). Developing successful, creative\&cultural clusters.Berlyn:Projekt Zukunft.

13. KlasterLT. (2017, March). Apžvalga (Review). Retrieved March 2, 2017, from: http://www.klaster.lt/lt/klasteriailietuvoje/apzvalga. (in Lithuanian).

14. Kuah, A.T.H. (2002). Cluster Theory and Practice: Advantages for the Small Business Locating in a Vibrant Cluster. Journal of Research in Marketing and Entrepreneurship, Vol. 4, No. 3, 206 - 228.

15. Lietuvos klasterių žemèlapis (Lithuanian Cluster Map). Apžvalga (Review). Retrieved March 2, 2017, from: http:// www.maps.klaster.lt. (in Lithuanian).

16. Lasionis, D. (2016). Susitelkę verslininkai ị regionus pritraukia daugiau turistų (Entrepreneurs clustered into regions attract more tourists). Retrieved March 2, 2017, from: http://www.enterpriselithuania.com/en/news/naujienos/ susitelke-verslininkai-i-regionus-pritraukia-daugiau-turistu/348. (in Lithuanian).

17. Mills, K., Reynolds, E., \& Reamer, A. (2008). Clusters and Competitiveness: A New Federal Role for Stimulating Regional Economies. Metropolitan policy program at Brookings.

18. Milone, P., \&Ventura, F. (2004). Novelty as Redefinition of Farm Boundaries. Seeds of Transition, VanGorcum, Assen.

19. Mrazauskaite, L. (2016). Klasterių populiarumą skatina poreikis kooperuotis (Cluster popularity driven by the need to co-operate). Retrieved March 2, 2017, from: http://zinios.lt/lzinios/ekonomika/klasteriu-populiaruma-skatinaporeikis-kooperuotis/205504. (in Lithuanian).

20. Navickas, V., \& Malakauskaitè, A. (2009). Pažangios užsienio šalių patirties diegimas formuojant turizmo klasterius Lietuvoje (Advanced Foreign Experience Forming a Tourism Cluster Lithuania). Taikomoji ekonomika: sisteminiai tyrimai, Nr. 3. Kaunas: VDU. (in Lithuanian).

21. Oyarce-Gatica, A., \& Mardones, M. (2012)."Logic of Economic Development: University Library and Industrial Clusters. El profesional de la información, Vol. 21, No. 6.

22. Pasiliauskas, M. (2012). Klasteriai Lietuvoje: kartu lengviau, bet ar norime? (Clusters Lithuania: Sometimes It's Easy, but if We Want to?) Retrieved March 3, 2017, from: http://www.technologijos.lt/n/mtl/S-29159/straipsnis/KlasteriaiLietuvoje:-kartu-lengviau-bet-ar-norime?1=1\&p=1. (in Lithuanian).

23. Porter, M.E. (2000). Location, Competition, and Economic Development: Local Clusters in a Global Economy. Economic Development Quarterly, Vol.14, No. 1, 15 - 34.

24. Razmaitè, I. (2013). Automobilių dalių gamintojai susibūrè ị klasterị (Car Parts Manufacturers Have Gathered in the Cluster). Verslo žinios. Retrieved March 2, 2017, from: http://vz.lt/article/2013/5/9/automobiliu-daliu-gamintojaisusibure-i-klasteri. (in Lithuanian).

25. Rosenfeld, S.A. (2002). Creating Smart Systems. A Guide to Cluster Strategies in Less Favored Regions. Brussels: European Commission.

26. Stalgienè, A. (2010). Klasterių vystymosi barjerai (Cluster Development Barriers). Management Theory and Studies for Rural Business and Infrastructure Development, Nr. 5 (in Lithuanian).

27. Švetkauskas, $\check{C}$. (2003). Pramonès sektoriaus klasterizacija Lietuvoje (Industrial Sector Clustering in Lithuania). Euroverslo naujienos, Nr. 34. Retrieved March 2, 2017, from: http://www.verslobanga.lt/lt/leidinys.full/3fc61c2d51d2f. (in Lithuanian).

28. Zadeh, R.M. (2007). Cluster Development and Initiatives in Traditional Industries. Paper for International Cluster Conference: Patterns of Clusters Evolution, Yorkshire Forward, Brussels.

29. Žinių ekonomikos forumas. (2012). Klasterių studija (Cluster Study). Vilnius: Žinių ekonomikos forumas (in Lithuanian). 